
Greeting's from the Engi-
neers' Club

BY T. COMMERFORD MARTIN.

To our fellow engineers, who've been looking many years,

Uptown and down, for a home whose rental wasn't high;

We, members of the Club, which has also felt that rub,

Bring greetings from our Little House nearby.

With you we share the gift; with yours, our voices lift

In praises of Carnegie, who aimed our kindred fate to tie.

"A home for you all" is graven on your wall,

And, deeper, on the cozy Little Club nearby.

Here may brethren dwell in peace; here may your tribes increase;

Here may the founts of knowledge ne'er run dry.

But for leisure moments sunny, or refreshing milk and honey,

Come over to the kindly Little House nearby.

When weary of the jargon of $4 \pi$ and of argon,

And of engineering problems that daily multiply;

Just step across the alley, or by the high bridge sally,

To the solace of the cheery Little Club nearby.

You are mining or electrical, railway or mechanical,

All for truth and fact and data in full cry;

But in the Club we're human-not forgetting there is woman-

And all are welcome in the Little House nearby.

To us within these walls, to all fair science calls.

Onward and upward as our temples pierce the sky!
So to your flow of soul, we shall pledge a brimming bowl,

Comrades! playmates! in the Little Club nearby.

JонN W. LieB, Jr.: It has always been one of the features of the social life connected with our professional engineering bodies that they have fraternized, not only among themselves, that they have spread their hands across the sea to their brothers in foreign lands. We have had numerous interchanges of visits, and it is always a welcome occasion that brings anew the opportunity of seeing our friends from abroad.

Among the distinguished guests that we have with us to-day is an old friend of many of the members of the engineering societies, and I shall call upon the special representative of the Institution of Electrical Engineers of Great Britain, Sir William Henry Preece.

\section{Address by Sir William Henry Preece, K.C.B., F.R.S.}

It is an old Latin proverb which says, Poeta nascitur, non fit, which roughly translated is, poets are born and not made.

We have had before us just now an unknown poet, and I must say I think we shall all agree that he must have been born so, for the natural tendency in the matter-of-fact business that he is engaged in is not one that would aid him in pouring forth such a beautiful welcome in such charming words.

I am here as an engineer who believes in facts. I was not born a poet, and it is my duty as the representative of the British Institution of Electrical Engineers to express for them the great pleasure we have in supporting the new movement that has taken place here, or rather in taking part in the exercises which are culminated in this meeting to-day.

I think that my friends at home must have been afraid of my being tempted elsewhere during this week, for they 
have sent me a message to remind me of what my duty ought to be. I received this morning a message which says:

"The president and council of the Institution of Electrical Engineers send most cordial greetings to the sister institute on the occasion of the dedication of their new home."

I would say, speaking as a member of the Institution, that it gives me the geatest pleasure to be here; and I can say more on my own behalf, that I appear here not only as the representative of the English institution of Electrical Engineers, but also, as you will see by this badge, as an Honorary Member of the American Institute of Electrical Engineers. In fact, I hold a unique position. It is a kind of a duplex position, for there are only two honorary members-one is Lord Kelvin, and the other is W. H. Preece. And I was about to say that there is no honor that I hold higher than the position of Honorary Member of your Institute.

I felt strongly inclined, when Professor Hutton referred to the functions of the engineering societies, to tell him that if one wants to know a little something of the history of the mechanical engineer he should study his Bible, for there he will find in one of the earlier chapters of Genesis that, according to the King James version, "Tubal-cain was an instructor of every artificer in brass and iron."* So then we learn, that in very early days there was something like technical education. That version has been revised in the new edition, and it says: "Tubal-cain was a forger of every cutting instrument of brass and iron." I hope that Mr. Hatfield, who represents the great industry of cutting tools in Sheffield, will take back home with him this fact that I have found for him, if he did not know it before, in a very old book which I am glad to say many of us read as often as we possibly can.

Sir, I do not know the time that you are going to allot to your speakers, but

\footnotetext{
*Genesis IV, 22.
}

I can say this, that anybody here who is anxious to hear me on these pointsI am such a crank in speaking about what engineering has done, and what engineering is that I can go on as long as to-morrow morning. Eschewing engineering subjects for the moment, I wish to say that it is with earnest feelings of pleasure and delight that I come to take part in the proceedings of your Institute. Nothing gives me so much pleasure as to come across the Atlantic, for I find that I can go back home with energy renewed, charged with energy such as we do not know at home until we have been over here. I am impressed always with the advances made, and I am glad to think I have had the opportunity and I hope I shall have it again, to impress upon my fellow-countrymen the advantages of coming across the ocean to see you.

Brief congratulatory remarks were then made as follows:

On behalf of the American universities, by Mr. Walter C. Kerr, trustee of The Cornell University.

On behalf of the Iron and Steel Institute of Great Britain, by Mr. R.A. Hatfield. Mr. Hatfield presented the United Engineering Society with an illuminated manuscript from the Iron and Steel Institute, the Institution of Civil Engineers, and the Institution of Mechanical Engineers of Great Britain.

On behalf of the Freibund Deutscher Elecktrische Technic, by Dr. Frederick Eichler.

On behalf of the American Society of Civil Engineers, past-president John Findlay Wallace read the following letter from president G. H. Benzenberg:

" Though not a member of either of your societies, I would like to have joined with you in giving hearty expression and acknowledgment of the splendid and generous recognition which $\mathrm{Mr}$. Carnegie has given to American engineers by this magnificent gift. This recognition of the achievements of the 
profession should stimulate and inspire every one of us to a higher accomplishment and to nobler purposes, so that the lofty motive which actuated the donor when he formulated his proposal may have its warrant in the further progress made by the engineer in every branch of his profession, between which no envy or rivalry should ever exist, excepting that contention of the engineering profession in every branch for the benefit of the profession at large.

May this home be a monument to the eminence and standing which the engineer has attained in every branch of the great industrial advancement of this country, and may his further progress and success in the economical development of the resources of nature for the use and benefit of man bring to him the full recognition he shall deserve.

Please accept and convey my sincerest good wishes and congratulations to the societies upon this occasion of the memorable opening of their new home, and may the spirit of peace, progress, and prosperity ever dwell within its walls."

\section{Address of Dr. Henry Prit- chett}

President of the Carnegie FoundATION.

We who labor in the preparation of men for the calling of the engineer feel a keen interest in your success and in your gift, and, for two reasons; first, because we have seen here an effort towards coöperation and unity, and we feel that progress is in accord with the spirit of the age. There could be no more fitting time to dedicate such a building as this, occupied and to be held by the engineering societies, than at the time of the meeting of a great peace conference. Secondly, we feel a great interest in this evidence of prosperity on the part of your societies, because it is a recognition of the dignity and of the value of the calling of the engineer.

After all, the engineer is the real civilizer of to-day, is the real advance agent of civilization and of culture. I cannot but think that such a building engineering could have been given no more fittingly by any one than by a man born in Scotland, because Scotland was civilized by engineers. There is a tradition that it was done by the poet and by the priest and by the university, but as a matter of fact it was done by the engineer.

The story is a short one. At the end of the eighteenth century the inhabitants of Scotland were still engaged in the noble business of lifting cattle from their southern neighbors. I have no doubt that the Carnegie clan got its full share. They had poets, they had prophets, they had universities, but they lacked civilization. Four engineers came along and civilized them. One taught them how to build roads, and his name is perpetuated to-day in the street pavement known as the Telford. The second taught them how to build a bridge across a stream. A third, and perhaps he was the greatest of all, taught them how to harness the power of steam. The fourth taught them how to draw a wagon on two rails with steam power. Those four men did in fifty years more than all the poets and prophets and universities had not done in a thousand years; they changed the country from a generation of cattle lifters to a generation of civilized men.

Speaking in all seriousness, sir, this building is of greatest moment to us because it does recognize that very fact. Your engineer is to-day the real worker in civilization. He is not a poet, he is not a prophet, he is not a priest; but he is a constructor. He represents the constructive side of human development, not the destructive side or the passive side, and as such he is the real maker of the civilization of our day.

What is it that makes civilization? What is it that civilized Scotland? It was the making of transportation, it was the bringing of men together; for it is not weakness that brings war and that makes peace impossible, but it is the ignorance, the lack of knowledge of one 